\title{
Motives and Obstacles of Using Internet as A Source for Learning By The Students of Human Sciences at the World Islamic Science \& Education University( WISE)
}

\author{
Mohammed Bader Alyousef ${ }^{1, *}$ \\ ${ }^{1}$ World Islamic Science \& Education University, Amman, Jordan \\ *Correspondence: World Islamic Science \& Education University, Amman, Jordan. E-mail: \\ kolod_hussein@yahoo.com
}

Received: June 17, 2015 Accepted: October 8, 2015 Published: March 29, 2016

doi:10.5296/ije.v8i1.7685 URL: http://dx.doi.org/10.5296/ije.v8i1.7685

\begin{abstract}
The study aimed at revealing the motives and the obstacles of using internet as a source of learning by the human colleges at WISE. And to achieve the study's goals, a questionnaire was developed consisting of 40 items; 20 items addressed motives of using internet as source of learning and other 20 items addressed obstacles of using internet as a source of learning . The sample of the study which consisted of 520 male and female students was selected randomly in the second semester for 2012/2013. After data were collected, they were analyzed using descriptive methods, t-test and ANOVA. Results showed the motives of using internet ranged from high degree to moderate. The degrees of obstacles facing using internet were moderate.

The researcher recommended the necessity of activating the students' use of internet with their teachers' guidance, facilitating the use of internet by increasing the number of computer labs and supervisors, in addition to provide flexible and easy electronic programs for studying university courses.
\end{abstract}

Keywords: education, Internet, motives, obstacles 


\section{Introduction}

In light of the technology development, many technology innovations have shown up as the computer, internet, Satellites and as a result many new concepts have emerged related to education process as: e-learning, e-library,...etc. the traditional education is no longer capable to meet the educational institutions' requirements in the era characterized by knowledge and technology skills especially in the field of preparing and training the human resources and the technicians in addition to be updated with the modern international attitudes in the field of education and improving the outcomes of the educational process (Champan,2006; Ajloni,2009).Introducing the modern technology into the field of education and considering it as a method in thinking and approach in work and a technique in solving the problems regardless it is a systematic process including the outcome of interaction a set of factors represented by equipments, machines, ideas, opinions, management in addition to human factor (Mackes, 2006).

And internet is considered the greatest achievement of the technology revolution in the methods of interactive communication as voice mail, chat, email, interactive video, visible conferences, ...etc) and so internet is easier to be used than other means of communications; the user of internet can travel all around the world listening and reading whatever he wants and meeting different friends from different countries that enable him to acquire new knowledge, experience and attitudes (Filfi,2006).

It is possible to get benefit from internet to make changes in the educational field; making changes in the structure of education, juused in teaching and so the learning and teaching system has been supported (Hamdi, 2004).

Internet has helped in providing information and the learning situations that achieve the educational goals and the ability to research and investigate. Therefore, the desire to use internet in the educational process has been increased (Aboud, 2007).

Alajloni(2014) believes that some justifications encourage using internet in education; helps in obtaining information from databases, research centers and libraries from different places in the world with less time and effort in addition to provide entertainment using events and images. Moreover, it gives new roles for the teacher and the learner. He also points that there is a need to renew education to meet the era of information in addition to use internet to make learning process more flexible so as the learner can create, rely on himself and think creatively.

Charp(2000) mentions that UNESCO conducted a survey study reviewed ninety studies addressed internet role in the educational process. Its results assured that internet has positive and effective role in the educational role as it increases self learning, improves communication skills and increases students' motivation towards learning.

Learning based internet can achieve many goals as: supplying students, teachers and the principals with the information that meet their needs, providing education to everyone at everywhere, helping in filling the digital gap between modern technology and integrated with the school curricula, supplying the teachers with the means that help them to send ideas to 
their students, designing curricula based on the students' individual differences. Additionally, students can browse the curricula and their content and they can communicate with their teachers using different means as emails. Teachers can guide through the study groups and design the educational content, prepare exams, and give homework(al-yusif,2014).

The great challenges facing the educational system are many and complicated as the revolution of information and communication followed by knowledge explosion, high demand of education in light of the increase of the number of population, realization of education's importance in development, the change of the teacher's role as the main source of knowledge to a secondary one, and the changing of the student's role as negative receptive depending on memory to a positive participant depending on access ways into the knowledge resources and use them efficiently (Sobhi,,2001).

Using internet as an assistant element in the educational process is a necessity to achieve the aims of the educational institutions for its many advantages as (Lal, 2002)

1. Access into information resources

2. Access into the statistics, research tools, images, sounds and news and get benefit of them.

3. Helping in doing homework through the big number of available references in the internet.

4. Possibility of consulting the teachers and experts via internet.

5. A suitable mean for following up the daily activities and the exams' results.

6. Communicating with others and get benefit of them through common learning and exchanging ideas and experiences.

The problem of the education could be solved by utilizing the great abilities that technology offer if we understand that the educational reform process is the output of the interaction between education, society and technology(Merrill, 2002).

And many researchers draw a perspective image of the curricula and their main features that assert new patterns of knowledge, information and skills as the skill of employing the computer and using internet and any other related issue with technology in all the school's levels. And this perspective image emphasizes on building the scientific character that can access into the knowledge through its different resources and can master the skills of scientific and critical thinking and problem-solving (Hazmi, 2005).

And Merill (2002) confirms that the effective use of education technology requires educational reform where there is a need to reconsider the curricula adding the skill of getting the information from any source to other skills as reading, writing and calculating and becomes one of the basic skills.

And the universities pay attention to prepare the human who is considered the capital of any civilized effort through providing the academic atmosphere in addition to specialized research centers. And the universities' opening of internet centers in the campus is considered another source of information that aims to supply the researchers with the updated 
information in a rapid changeable world (Enzi, 2010).

\subsection{Problem of the study}

The university students has a great responsibility for preparing himself to get benefit from the opportunities and the cognitive capabilities which the university provide to be ready academically and scientifically in his specialization so the modern methods of teaching tend to use the appropriate means of teaching that allow developing talents and the students' self capabilities. Therefore, universities seek to be a cognitive and scientific center inside and outside the society for its capabilities that help in facilitating knowledge and for its desire to create positive attitudes towards scientific research which related to society development. University has to take its place in the science research for preparing specialized and researchers according to social and economic plan that accelerate development.

To be improved academically and scientifically, the students should work hard in search for knowledge through centers and internet labs which the university creates for its belief that information which the students need in the era of information revolution increases. University education in light of internet seeks to achieve the best investment of time and effort of the students who look for information and knowledge. So this study aims to look for the motives and obstacles of using internet as a source of learning by the students of The World Islamic Science \& Education University(WISE).

\subsection{Study’s questions}

1- What are the motives of using internet as a source of learning of the students of human colleges at The World Islamic Science \& Education University(WISE)?

2- Are there statistical significant differences of the motives of using internet as a source of learning attributed to gender or college variable?

3- What are the obstacles of using internet as a source of learning of the students of human colleges at The World Islamic Science \& Education University (WISE)?

4- Are there statistical significant differences of the obstacles of using internet as a source of learning attributed to gender or college variable?

\subsection{Procedural definitions}

Internet: it is the international network used by university students university to obtain information and everything related to their assignments.

Motives: reasons force the students to use internet as a source of learning inside the university.

Obstacles: difficulties facing the students in using internet as a source of learning inside university.

\subsection{Previous studies}

After reviewing the educational literature and the previous studies in this field, the researcher 
get benefit of many related studies in terms of methodology, data collection procedures and treatment. These studies will be presented as follows.

And the study of Obada(1999)aimed to identify the extent of the teachers and the students' awareness of the importance of using internet in the field of education, the extent of their getting benefit of using internet and the most important problems that hinder their use of internet. The sample of the study consisted of 88 male and female teacher and student from different specializations. To collect data, the study adopted the personal meeting and field visits. A questionnaire consisted of 36 items about the awareness on internet importance in education and obstacles of using internet. The results showed high use of internet among the teachers of science and English language while it is less among the teachers of social studies and Arabic. And the most problems facing them were lack of training courses and the language which internet deals with in addition to the slowness of internet lines

The study of Rakes (1996) about the use of internet as a tool to apply information basis in the learning environment. The study showed the students' need to the update information to face the valid academic requirements that help in solving their problems. The researcher in the study designed a school plan that showed the use of internet as a source of information in studying hall illustrating the way of cognitive communication between the net users to achieve long0life learning through building data basis

And the study of Schrum and lamp (1997) aimed to identify the adequacy and the effectiveness of using internet in education showing different strategies of learning using group ware and the on-line strategy. The study came up with different suggestions as the necessity of using internet as a major tool in cooperative learning and distance learning.

Tayi conducted a study (2000) addressed the use of internet in Arab World. The sample of the study consisted of 5000 male and female students from university students representing Egypt, Saudi, UAE, Bahrain, and Kuwait. Results showed $72.6 \%$ of the sample used internet. Internet was considered important for $91.5 \%$ of the sample and entertainment was the second reason for using internet followed by the use of emails with 59.3\%. Additionally, there were no significant differences in the fields of using internet attributed to gender variable.

Omari's study (2001) aimed to investigate the status of using internet by the academic staff and the students at The Jordan University of Science and Technology the sample of the study consisted of 124 academic staff members and 236 male and female students from different colleges. Results showed $50 \%$ of the sample uses internet daily, $45 \%$ weakly and $75 \%$ of the academic member can use the internet perfectly. Additionally, there were no statistically significant differences between the respondents' answers attributed to the college, or gender, or having connection with internet service. Moreover, results showed 11 reasons for the students' use of internet which are totally different from the academic staff's reasons. There were statistically significant differences between the means of the respondents' responses attributed to their ownership to computers and their linkage with internet service.

And a study of Boaza(2001)aimed to identify the status use of internet by the students of Sultan Qaboos University. The researcher distributed a questionnaire consisted of 17 items 
into 304 student of Engineering, sciences, Commerce and agriculture faculties. The study was limited to the students of the second year and above. The results showed that scientific research and communicating via e-mails came in first rank in purposes of using internet followed by school curricula services and search for information, speaking and reading newspaper, continuous learning and entertainment, shopping and playing games respectively. The results also showed that Infoseek, Yahoo, Lycos and Excite were the most search engines used. And the students faced many problems during using internet as slow connection, or disconnection or overcrowding in computers' labs and the inability of identifying the suitable websites and lack of English Language proficiency.

And fleck \& Mcqueen (2002) conducted a survey study on the uses of internet in the American colleges and universities. The researchers distributed a questionnaire, consisted of 12 items, into 60000 male and female students in 13 American university and college but the proportion of the retrieved questionnaires was very low around $16 \%$. And the results showed that the universities and colleges' students have high use of internet especially in the fields related to their studies. And the highest proportion of use in the field of education and access into the virtual lectures via internet but the results pointed to problems concerning designing websites; some sites have scientific mistakes.

Ababna`s study (2003) aimed at identifying the extent of using internet as a source of leaning by high studies' students and the obstacles facing this use. The sample of the study consisted of 638 male and female students from University of Jordan and Yarmouk university. Results revealed statistical significant differences in getting benefit of internet attributed to university variable in favor of University of Jordan while there were no statistical significant differences to the extent of getting benefit of internet attributed to gender, academic timetable, college. Additionally, results showed the most significant reasons for using internet were wasting time, looking for universities that present scholarships and looking for immigrations means.

Ghomd's study (2003) aimed to reveal the use of internet as a source of learning. The sample of the study consisted of 341 male and female students of Yarmouk university and The Jordan University of Science and Technology who use internet. Results showed different applications of internet were few and the efficiency degree of using internet as a source of learning and the degree of the obstacles were moderate. Results also showed statistical significant differences in using internet as a source for learning attributed to language of the study in favour those who study using English and there were statistical significant differences in using internet for general purposes attributed to gender in favour of the males.

Mansour conducted a study (2004) aimed at revealing the motives for using internet. The sample of the study consisted of 330 male and female students from University of Bahrain. Results showed the first motive for using internet was looking for knowledge followed by entertainment and social relations. There were no differences in the motives of using internet attributed to gender variable while there were significant differences in the field of information attributed to college variable in favour students of Education college. Results also revealed significant differences in the field of social integration attributed to the length of using internet variable in favour of users for more than three years. 


\section{Macrothink}

International Journal of Education

ISSN 1948-5476

2016, Vol. 8, No. 1

The study of Rivera\& Rice(2005) compared the effect of education via internet and blending education in the students' achievement and their satisfaction. The sample of the study consisted of 134 students of Business management distributed into three groups. The researchers used an achievement test and a questionnaire to measure the respondents' satisfaction. Results showed the students' achievement who studied via internet was highest. The students who learn via internet have the highest level of satisfaction.

\section{Methodology \& procedures}

\subsection{Population of the study}

The population of the study consisted of all the students who enrolled in the colleges of Art, Educational sciences and Law in the second semester for the year 2013-2014 as it illustrated in table 1.

Table 1. Population of the study

\begin{tabular}{|c|c|c|c|}
\hline College & Males & females & Total \\
\hline Art & 191 & 274 & 465 \\
\hline Educational sciences & 231 & 260 & 491 \\
\hline Law & 280 & 293 & 573 \\
\hline Total & 702 & 827 & 1529 \\
\hline
\end{tabular}

\subsection{Sample of the study}

The sample of the study which was selected randomly consisted of 530 male and female students. The questionnaires were distributed to the sample and 520 questionnaires were retrieved and they were valid for analysis.

Table 2. The sample of the study

\begin{tabular}{llllc}
\hline College & Males & females & Total & $\%$ \\
\hline Art & 95 & 120 & 215 & $\% 41.3$ \\
Educational sciences & 88 & 97 & 185 & $\% 35.5$ \\
Law & 83 & 37 & 120 & $\% 23.2$ \\
Total & 266 & 254 & 520 & $\% 100$ \\
\hline
\end{tabular}

\subsection{Instrument of the study}

The reviewed the previous studies and related literature to prepare the instrument which consisted of 40 items. Fifth -Lickert scale was adopted very high (5), high(4), moderate (3), 


\section{Macrothink}

International Journal of Education

ISSN 1948-5476

2016, Vol. 8, No. 1

low(2), very low(1), and the degrees for the competencies were as follows: very high(4.5=5), high (3.50-4.49), moderate (2.5-3.49), low (1.5-2.49), very low ( 1-1.49).

\subsection{Validity \& reliability of the instrument}

The instrument was presented to a group of specialized arbitrators in the Jordanian universities and their comments and suggestions were taken into account in terms of the instrument's items' language and clearness.

To check the instrument's reliability, reliability coefficient was calculated by internal consistency method using Cronbah Alpha and the reliability values were between $81 \%-87 \%$ which were considered appropriate for the conducting this study.

\subsection{Statistical treatment}

The researcher used the following:

1. Means and standard deviation

2. T test for differences of means

3. Chronbach Alhpa for internal consistency to identify the tool's reliability.

4. One way ANOVA test

\section{Results \&discussion}

First question:

What are the motives of using Internet as a source of learning for the students of The World Islamic Science \& Education University?

To answer this question, means and standard deviation were calculated.

Table 3 illustrates that items with rank from 1-9 have high degrees with means range between (3.64-3.83) with standard deviations range (0.64- 0.72), and the items with ranks (10-20) have moderate degrees with means range (2.71-3.35) with standard deviations range( 0.75-0.62).

This result attributed to the students' perception of the importance of the Internet in learning process, availability of the information that help them in doing their homework, university's encouragement for using Internet and the subscription in international databases. 


\section{MInstitute Macrothink}

Table 3. Results of the first question

\begin{tabular}{|c|c|c|c|c|c|c|}
\hline $\mathrm{N}$ & Rank & Items & $\mathrm{M}$ & Std & Ratio\% & Degree \\
\hline 11 & 1 & $\begin{array}{l}\text { Using internet helps me to get information } \\
\text { quickly. }\end{array}$ & 3.8333 & 0.64 & $\% 81$ & High \\
\hline 12 & 2 & $\begin{array}{l}\text { University motivation to use internet to } \\
\text { improve education quality }\end{array}$ & 3.7600 & 0.66 & $\% 79$ & High \\
\hline 13 & 3 & Availability of computer labs at university & 3.6933 & 0.64 & $\% 76$ & High \\
\hline 14 & 4 & Internet helps in getting update information & 3.6867 & 0.68 & $\% 73$ & High \\
\hline 15 & 5 & Internet helps in getting reliable data & 3.6733 & 0.71 & $\% 72$ & High \\
\hline 16 & 6 & $\begin{array}{l}\text { Using internet helps in getting information } \\
\text { from known sources }\end{array}$ & 3.6700 & 0.72 & $\% 70$ & High \\
\hline 17 & 7 & The information I get are sufficient & 3.6633 & 0.62 & $\% 69$ & High \\
\hline 18 & 8 & $\begin{array}{l}\text { Using internet helps in skipping alternative } \\
\text { sources }\end{array}$ & 3.6533 & 0.76 & $\% 68$ & High \\
\hline 19 & 9 & $\begin{array}{l}\text { Using internet helps to get information } \\
\text { which are scientifically Refereed }\end{array}$ & 3.6433 & 0.72 & $\% 67$ & High \\
\hline 1 & 10 & $\begin{array}{l}\text { Using internet helps in planning to follow } \\
\text { up my lessons }\end{array}$ & 3.3458 & 0.62 & $\% 66$ & Moderate \\
\hline 2 & 11 & $\begin{array}{l}\text { Using internet enhances my desire to do } \\
\text { educational activities }\end{array}$ & 3.2447 & 0.66 & $\% 65$ & Moderate \\
\hline 3 & 12 & $\begin{array}{l}\text { Using internet enhances organizing my } \\
\text { schedule all the year. }\end{array}$ & 3.1573 & 0.61 & $\% 64$ & Moderate \\
\hline 4 & 13 & $\begin{array}{l}\text { Using internet helps me interact with my } \\
\text { colleagues }\end{array}$ & 3.0145 & 0.66 & $\% 63$ & Moderate \\
\hline 5 & 14 & $\begin{array}{l}\text { Using internet helps me organizing } \\
\text { educational experiences }\end{array}$ & 3.0004 & 0.69 & $\% 63$ & Moderate \\
\hline 6 & 15 & $\begin{array}{l}\text { Using internet develops my critical } \\
\text { thinking skill }\end{array}$ & 2.9987 & 0.59 & $\% 62$ & Moderate \\
\hline 7 & 16 & $\begin{array}{l}\text { Using internet helps me reading articles } \\
\text { related to my study's field. }\end{array}$ & 2.9845 & 0.71 & $\% 62$ & Moderate \\
\hline 8 & 17 & $\begin{array}{l}\text { Using internet helps me searching through } \\
\text { e-library and databases. }\end{array}$ & 2.9753 & 0.75 & $\% 61$ & Moderate \\
\hline 9 & 18 & $\begin{array}{l}\text { Using internet helps me to evaluate my } \\
\text { learning }\end{array}$ & 2.9658 & 0.66 & $\% 60$ & Moderate \\
\hline 10 & 19 & $\begin{array}{l}\text { Using internet helps me diagnose weak } \\
\text { points in my achievement }\end{array}$ & 2.9521 & 0.61 & $\% 58$ & Moderate \\
\hline 11 & 20 & Using internet helps me to save financially & 2.7145 & 0.75 & $\% 55$ & Moderate \\
\hline
\end{tabular}

Second question: Are there statistical significant differences to the motives of using internet as a source of learning attributed to gender or college variables? To check if there were statistical significant differences to the motives of using internet as a source of learning attributed to gender variable, $\mathrm{T}$ test was used as it is illustrated in table 4.

Table 4. Results of $\mathrm{T}$ test for the differences between males and females in the motives of using internet as a source of internet

\begin{tabular}{llllll}
\hline Gender & $\mathrm{N}$ & $\mathrm{M}$ & $\mathrm{Std}$ & $\mathrm{T}$ & Sig. \\
\hline Males & 266 & 21.2935 & 4.3261 & \multirow{2}{*}{$0.95-$} & \multirow{2}{*}{0.33} \\
Females & 254 & 21.9483 & 3.6343 & & \\
\hline
\end{tabular}


It is clear from table 7 that value of calculated t was not statistically significant so there were no statistical significant differences to the obstacles of using internet as a source of learning for the students attributed to gender variable.

This result may attribute to the respondents' total agreement as they the same circumstances at the university; attending lectures in the same classes and doing the same activities inside the university.

To check if there were statistical significant differences in the motives for using internet as a source of learning attributed to college variable, ANOVA was used as it is illustrated in table 5 .

Table 5. ANOVA test of motives of using internet attributed to college variable

\begin{tabular}{llllll}
\hline Source of variance & Sum of seq. & Df & M of seq. & F & Sig. \\
\hline Between groups & 46.851 & 3 & 15.617 & & \\
Within groups & 2371.122 & 516 & 16.241 & \multirow{2}{*}{0.96} & 0.41 \\
Total & 2417.973 & 519 & & & \\
\hline
\end{tabular}

It is clear from table 5 that value of calculated t was not statistically significant so there were no statistical significant differences to the obstacles of using internet as a source of learning for the students attributed to college variable. This result may due to the fact that the students face the same obstacles in using internet because they have the same circumstances at the university.

Third question: What are the obstacles of using internet as a source of learning of the students of human colleges at The World Islamic Science \& Education University(WISE)?

To answer this question, the mean and the standard deviations were calculated as it is illustrated in the following table.

Table 6. The means and standard deviations of the obstacles of using internet as a source of learning

\begin{tabular}{|c|c|c|c|c|c|c|}
\hline $\mathrm{N}$ & Rank & Items & M & Std & Ratio \% & degree \\
\hline 11 & 1 & $\begin{array}{l}\text { Information in internet are published in } \\
\text { English }\end{array}$ & 3.320 & 0.76 & $\% 77$ & Moderate \\
\hline 12 & 2 & $\begin{array}{l}\text { Lack of time allocated to students to use } \\
\text { internet }\end{array}$ & 3.1733 & 0.82 & $\% 72$ & Moderate \\
\hline 13 & 3 & $\begin{array}{l}\text { Lack of information published in Arabic in } \\
\text { internet }\end{array}$ & 3.000 & 0.75 & $\% 69$ & Moderate \\
\hline 14 & 4 & $\begin{array}{l}\text { Lack of educational sites related to } \\
\text { specialization }\end{array}$ & 2.9733 & 0.71 & $\% 68$ & Moderate \\
\hline 15 & 5 & Difficulty of search method for information & 2.9333 & 0.64 & $\% 67$ & Moderate \\
\hline 16 & 6 & Weak guidance in the labs & 2.9133 & 0.80 & $\% 66$ & Moderate \\
\hline
\end{tabular}




\section{Macrothink}

International Journal of Education

ISSN 1948-5476

2016, Vol. 8, No. 1

\begin{tabular}{|c|c|c|c|c|c|c|}
\hline 17 & 7 & Internet with low speed and response & 2.9067 & 0.73 & $\% 66$ & Moderate \\
\hline 18 & 8 & Difficulty of using the internet & 2.900 & 0.76 & $\% 66$ & Moderate \\
\hline 19 & 9 & $\begin{array}{l}\text { Lack of sufficient computers linked to } \\
\text { internet }\end{array}$ & 2.8733 & 0.77 & $\% 65$ & Moderate \\
\hline 1 & 10 & $\begin{array}{l}\text { Means for storing information are not } \\
\text { allowed in the labs }\end{array}$ & 2.7854 & .78 & $\% 64$ & Moderate \\
\hline 2 & 11 & $\begin{array}{l}\text { My belief internet has negatives more than } \\
\text { advantages }\end{array}$ & 2.7742 & .75 & $\% 63$ & Moderate \\
\hline 3 & 12 & Lack of alternative means of internet & 2.7001 & .73 & $\% 63$ & Moderate \\
\hline 4 & 13 & $\begin{array}{l}\text { Lack of sufficient centers for training to use } \\
\text { internet }\end{array}$ & 2.6945 & .77 & $\% 62$ & Moderate \\
\hline 5 & 14 & Lack of motivation for using internet & 2.6721 & .71 & $\% 60$ & Moderate \\
\hline 6 & 15 & $\begin{array}{l}\text { Asking for articles via internet is not } \\
\text { efficient }\end{array}$ & 2.6635 & .69 & $\% 59$ & Moderate \\
\hline 7 & 16 & Negative attitudes \& psychological barriers & 2.6547 & .68 & $\% 58$ & Moderate \\
\hline 8 & 17 & Weakness in privacy in dealing via internet & 2.6478 & .73 & $\% 56$ & Moderate \\
\hline 9 & 18 & Information in internet are worthless & 2.6321 & .74 & $\% 55$ & Moderate \\
\hline 10 & 19 & $\begin{array}{l}\text { Absence of laws organizing of cognitive } \\
\text { \&property rights }\end{array}$ & 2.6145 & .70 & $\% 53$ & Moderate \\
\hline 20 & 20 & Ignorance of using computer and internet & 2.590 & 0.74 & $\% 52$ & Moderate \\
\hline
\end{tabular}

It is clear from the previous table that the degree of all the items concerning the obstacles was moderate with means range (3.320-2.590) and standard deviations (0.76-0.74). The obstacle with the highest mean was: "information published in internet were in English", and the least one was: "ignorance of using internet and the computer", and this ratio indicates that the university students suffer from these obstacles. This result may due to the fact that the language study in these colleges was not English so the students of human colleges face difficulty in browsing internet looking for information for lack of Arabic content in Internet and technical problems.

Fourth question: Are there statistical significant differences to the motives of using internet as a source of learning attributed to gender, college variables?

To check if there were statistical significant differences to the obstacles of using internet as a source of learning attributed to gender, $\mathrm{T}$ test was used as it is illustrated in table 7 .

Table 7. Results of T test

\begin{tabular}{llllll}
\hline Gender & $\mathrm{N}$ & $\mathrm{M}$ & $\mathrm{Std}$ & $\mathrm{T}$ & Sig. \\
\hline Males & 266 & 19.8696 & 4.2972 & \multirow{2}{*}{0.82} & \multirow{2}{*}{0.41} \\
Females & 254 & 19.3103 & 3.5699 & & \\
\hline
\end{tabular}




\section{Macrothink}

International Journal of Education

ISSN 1948-5476

2016, Vol. 8, No. 1

It is clear from table 7 that value of calculated $t$ was not statistically significant so there were no statistical significant differences to the obstacles of using internet as a source of learning for the students attributed to gender variable. This result may due to the fact that the students face the same obstacles in using internet because they have the same circumstances at the university.

To check if there were statistical significant differences to the obstacles of using internet attributed to college variable, ANOVA was used as it is illustrated in table 8.

Table 8. ANOVA results concerning the obstacles of using internet according to college variable

\begin{tabular}{llllll}
\hline Source of variance & Sum of seq. & Df & M of seq. & F & Sig. \\
\hline Between groups & 41.235 & 3 & 13.745 & \multirow{2}{*}{0.80} & \multirow{2}{*}{0.34} \\
Within groups & 2514.235 & 516 & 17.220 & & \\
\hline
\end{tabular}

Table 8 showed that the value of the calculated t was not statistically significant at the level of (0.05) so there were no statistical significant differences to the obstacles of using internet as a source of learning attributed to college variable. The research attributes this result to the fact that the students pass by the same circumstances at the university regardless the college or the major.

\section{Recommendations}

In light of these results, the study recommended the following:

1. Activate the students' use of internet through increasing the labs' numbers and through the supervisors' cooperation in this activation process.

2. Using internet as an assistant resource in the school subjects.

3. Held training courses to the students of using internet.

4. Conduct further studies to identify the elements that can increase the efficiency of using internet as a source of learning and eliminate the obstacles facing its use.

\section{References}

Ababna, Z, W. (2003). Using internet as a source of learning of high studies' students and obstacles of using it. Unpublished thesis, Yarmouk University, Irbid, Jordan.

Aboud, H. (2007). Computer in Education. Dar Wael for Publishing, Amman.

Ajlouni, K, I. (2009). Status of using Information technology and communications by the 
high studies students in Educational sciences college. Derasat, 36, 433-448.

Ajlouni, K, I. (2014). Educational effects of using internet by the students of Open Arab University. Derasat, 41(2).

Al-enzi, S, F. (2010). Educational and social effects of using Internet from the perspective of secondary stage's students and their teachers and parents in Saudia Arabia. Unpublished dissertation, University of Jordan, Amman, Jordan.

Al-yusif, M, B. (2014). Efficiency of electronic course in Islamic Education through Moodle system in the ninth grade students' achievement and their attitudes towards it. Journal of Hussein bin Talal University, 3(1), 30-57.

Boeza, A, S. (2001). Status of using internet of University of Qaboos students. Journal of King Fahad Library, 6(2), 191-214.

Champan, C. (2006). Computer and internet use by students, institute of science education. Retrieved 20/10/2014 from http://Annenberglibrary blofspot.com

Charp, S. (2000). Internet Usage In Education. Technological Horizon In Education, 27(10), 12-14.

Filfi, H, H. (2006). Results achieved by university students' use of Internet , a paper presented to the third educational conference to the center of psychological and educational research. Baghdad University.

Fleck, R.T., \& Mcqueen, S.F. (2002). Internet Access, usage and policies in collage \& universities. Retrieved from http//www.firstmonday.dk/issues/issues4-11/Fleck

Ghmeid, I, H. (2003). Degree of Using Internet as a source of learning by the students in Yarmouk University \& University of science and technology. Unpublished thesis, Yarmouk University, Irbid, Jordan.

Hamdi, N. (2003). Educational uses of Internet at Jordanian Universities. Educational Sciences, 2, 1-34.

Hazmi, B, A. (2005). Status of Using Internet by academic staff and the students of teachers' colleges in Makah Mokarama Area, Unpublished Thesis, Um ALqura University, Saudia Arabia.

Lal, Z, Y. (2002). Internet in Education\& status of scientific research, obeikan Library, Ryadh.

Makes, S. (2004). The effect of using computer as a learning tool in a kindergarten $\begin{array}{lll}\text { curriculum, } & \text { Retrieved 29/11/2014. From }\end{array}$ http://proquestumi.com/pqdweb?Did=765622401sid

Mansour, T, B. (2004). Using Internet and its motives of students of Barain University: field study. Arab Journal of Human sciences -University of Kuwait, 22(86), 167-196.

Merrill, D. (2002). Effective use of instructional technology requires educational reform. 
Educational technology, 42(4), 13-17.

Omari, M, K. (2001). Status of using internet of academic staff an students of Jordan University of science and technology. Journal of Arab Universities Union, 40, 35-70.

Rakes, Glenda, C. (1996). Using The Internet as a tool in a Resource Based learning environment. Educational Technology, 36(5), 52-56.

Rivera, J., \& Rice, M. (2014). A Comparison of student outcomes and satisfaction Between Traditional and Web-Based course offering. Retrieved 12/ 9/2014 From http://westage.edu/distance/ojdla/fall35/rivera53.h1

Schrum, Lynne \& Theodore lamp. (1997). A computer networks as instructional and collaborative distance learning environment. Educational Technology, 37(4), 26-28.

Sobhi, A, A. (2001). Status of high studies' students' use of internet and their attitudes it. Unpublished thesis, Yarmouk University, Irbid, Jordan.

Tay`, S, A. (2000). Using internet in Arab World: field study on a sample of Arab Youth. Egyptian Journal of public opinion research, 4, 33-68.

\section{Copyright Disclaimer}

Copyright for this article is retained by the author(s), with first publication rights granted to the journal.

This is an open-access article distributed under the terms and conditions of the Creative Commons Attribution license (http://creativecommons.org/licenses/by/3.0/). 